\title{
Comparing Alternative Structures of Financial Alliances
}

\author{
Raimo Voutilainen \\ Helsinki School of Economics, Helsinki, Finland. \\ E-mail: r.voutilainen@kolumbus.fi
}

In this paper, we study alliances between banks and insurance companies. Our perspective is that of the top management of a financial enterprise, and we constrain ourselves to the retail market. We define six different structure models for financial alliances. The parameters of the models are the closeness of the alliance in terms of mutual ownership, and the question of whether alliance partners have overlapping service channels. Examples are given of the models in the Finnish banking and insurance market. We also characterize nine criteria according to which the previously defined models are to be compared to achieve the most attractive alliance model. Thus, we obtain a multi-criteria decisionmaking (MCDM) problem. In the design of the criteria, representatives of the top management of Finnish banks and insurance companies have been consulted.

The Geneva Papers (2005) 30, 327-342. doi:10.1057/palgrave.gpp.2510026

Keywords: financial alliances; financial convergence; financial conglomerates; multi-criteria decision-making; strategic planning

JEL classification: G21; G22; O21

\section{Introduction}

Networking and alliance formation have been growing trends in the financial industry during the past decades. In many European countries, it became almost an industrial practice in the late 1980 s to step over the borderline between banks and insurance companies. It was often banks that had calculated that it would produce good synergies to start up an insurance subsidiary, or perhaps both a life and a nonlife subsidiary, and then sell their products via the banks' own distribution network. In the 1990s, big financial conglomerates, which included both banks and insurance companies, emerged both in the U.S.A. and Europe.

The launching of financial conglomerates was generally based on the same hypothesis as intra-sector mergers: centralized ownership helps to achieve and utilize the critical mass and, thus, increase efficiency. It was also believed that different business lines could diversify the business portfolio and reduce the cyclicality of corporate performance. There are many firm supporters of financial conglomerates but as we entered the new millennium we also heard their opponents' statements. The diversification potential has been questioned both in theory and practice. The different attitude to risk in the banking and the insurance industries has worried some observers, especially in the insurance sector. On the other hand, because of the obvious benefits of cross-selling, some kind of alliance between banks and insurance companies 
is desirable. Therefore, one might ask what the most appropriate depth of an alliance is, given the financial institution's business objectives.

The term 'financial alliance' occurs seldom in the literature - when authors refer to groupings that are looser than conglomerates they often use the term 'financial convergence' (see next section). The scientific dialogue in this field is both scarce and rather pragmatic, and systematic approaches to selecting the best alliance model can hardly be found.

In the following we use the term 'financial alliance' to stand for an alliance between one or several banks and one or several insurance companies. The insurers in an alliance can be life and/or nonlife companies. Alliances between banks and nonlife insurance companies with no life counterparts are in practice rare. On the other hand, synergies between retail banking and life insurance are so significant that one often encounters alliances between banks and life insurers without nonlife counterparts.

Financial alliances often include units like mutual fund managing companies, asset management companies, securities brokerages and corporate finance companies, but for the sake of simplicity we restrict ourselves in this paper to the groups of banks and insurance companies. (In most European countries banks are allowed to be 'universal'. Consequently, it is customary that they include the above mentioned functions. The same holds increasingly for insurance companies.)

Some of the driving forces behind the alliance or networking trend are, as follows:

- narrowing profit margins in banks and insurance companies call for new sources of income by cross-selling;

- tight margins can also necessitate savings and cutoff programmes that can be more effectively carried out by a closer alliance structure;

- changing customer behaviour such as one-stop shopping requires cooperation between all financial service providers;

- international trade agreements are dismantling tariffs and breaking down barriers to trade allowing more companies to enter new markets; ${ }^{1}$

- regulators are espousing greater competition because they are recognizing the economic benefits to their countries and their customers; ${ }^{2}$

- cross-selling can play, and has played, an important role in preventing job losses and creating employment in the banking sector. ${ }^{3}$

The perspective in this paper is managerial. Another two possible perspectives would be the supervisory perspective (although there are common factors between these perspectives) and a customer's perspective. We also concentrate on the retail market alliance formation also has significance in relation to other customer segments.

In the following section, we give an overview of previous research related to financial alliances. In the next section we define six structure models for alliances, and give examples of the models in the Finnish banking and insurance market. In the following section, we suggest nine criteria according to which the previously defined models are to be compared to achieve the most attractive alliance model. In the

\footnotetext{
${ }^{1}$ Ryan (2001).

2 Ibid.

${ }^{3}$ Benoist (2002).
} 
penultimate section, we comment on the interviews of representatives of the top management of Finnish banks and insurance companies who were consulted in the designing of the criteria. In the final section we summarize the results that we have obtained.

\section{Overview of previous research}

Focarelli and Pozzolo ${ }^{4}$ point out that during the 1990s the number and value of mergers and acquisitions increased rapidly in virtually all sectors of economic activity. They were particularly frequent in the banking sector. Vander Vennet ${ }^{5}$ shows that financial conglomerates are more revenue efficient than their specialized competitors. His results are confirmed by Casu and Girardone. ${ }^{6}$

Financial convergence. The emergence of alliances is connected to financial convergence, which means a blurring of conventional boundaries of once discrete financial sectors. ${ }^{7}$ Converging sectors are assuming each other's tasks. Convergence is driven by a need for growth by entering new markets, and by the desire to maximize share of wallet from every customer. ${ }^{8}$ Van den Berghe and Verweire ${ }^{9}$ point out that one or another form of the financial convergence can be witnessed in many, if not all, developed markets.

Supervisory perspective. Convergence has brought about somewhat similar solvency regulation for the banking and insurance sectors. Bittermann and Lutz ${ }^{10}$ compare banking and insurance risks and points out that in Germany, for example, the convergence of the financial sectors has resulted in the merging of the respective supervisory authorities. On the other hand, Manghett ${ }^{11}$ comes to the conclusion that supervising even multinational financial conglomerates does not necessitate the convergence of supervisory authorities. Implications of financial convergence for supervision and regulation are discussed by OECD, Van den Berghe and Verweire and Verweire. $^{12}$

Shareholder aspects. Cybo-Ottone and Murgia ${ }^{13}$ study whether European crossproduct mergers have created positive shareholder value. They document positive results driven by the strong market reaction of deals announced between banks and insurance companies. Cybo-Ottone and Murgia explain this by economies of scope or revenue efficiencies due to cross-selling of bank and insurance products to retail customers. In the U.S., the Citicorp-Travelers Group merger in 1998 increased the prospects for new legislation to remove the barriers between banking and insurance,

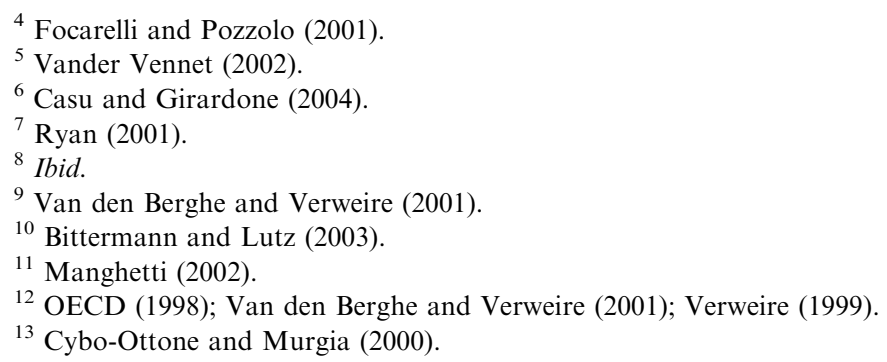


resulting in a positive wealth effect for institutions most likely to gain from deregulation. ${ }^{14}$

Diversification. Boyd et al. ${ }^{15}$ used hypothetical cross-product mergers and simulations and found risk reduction effects from these deals. Boyd and Graham ${ }^{16}$ found that life insurance companies seem to offer good prospects as matches for bankholding companies because of potential diversification gains. ${ }^{17}$

Estrella $^{18}$ examines direct measures of potential diversification gains from consolidation of financial firms. His results indicate that there may be bilateral diversification gains from mergers involving the banking and insurance industries. Estrella points out that these gains are not limited to life insurance as suggested by the previous authors, but extend to nonlife insurance companies, which actually lead to larger diversification gains than those with life insurance companies.

The emergence of alliances has also influenced finance product sales: according to SIGMA,${ }^{19}$ growing sales of life insurance in banks has increased, especially, unitlinked sales volumes.

\section{Structure models for financial alliances}

As we described in the previous section, the existing literature on financial alliances is strongly concentrated around alliances created by cross-sector ownership. The objective of this work is to create a model to find out if ownership really is superior to looser alliance models.

Alliance structures can be classified into three categories according to the degree of closeness of the members. The categories in increasing order of closeness are as follows:

Cross-selling agreements. The parties agree to sell each other's products to their own customers. (One can alternatively cross-sell by selling one's own products to the other party's customers. This can be recommended if the products are complicated. This type of cross-selling is often made more effective so that one party gives with the customer's permission his/her contact information to the other party for marketing their products.) The cross-selling is frequently one-sided. Most often a bank sells an insurance company's products to its customers. Life insurance products especially, depending on the tax system, can bring immediate added value to a retail bank's customer service process and they can be sold effectively by the bank sales force. ${ }^{20}$ Similar advantages for insurance companies are not so obvious. Generale and Gobbi ${ }^{21}$ show that the most efficient banks in developed countries earn a smaller percentage of

\footnotetext{
${ }^{14}$ See Carow (2001).

15 Boyd et al. (1993).

${ }^{16}$ Boyd and Graham (1988).

${ }^{17}$ See also Lown et al. (2000) and Laderman (1999).

${ }^{18}$ Estrella (2001).

${ }^{19}$ SIGMA (2003).

${ }^{20}$ Cf. for example, Van den Berghe and Verweire (2001); Benoist (2002).

${ }^{21}$ Generale and Gobbi (1999).
} 
their profits from traditional activities and a larger share from off-balance-sheet operations (such as life insurance and mutual fund sales).

This alliance category can still be divided into two subcategories depending on whether the parties' service channels are overlapping or not. Here a service channel can be a branch office network, but also a call centre or website, etc. Especially in the case of overlapping branch networks one easily faces channel conflict: the alliance members do not cooperate effectively due to the fear of losing their customers to the other party and consequently such items as sales provisions. Basically, overlapping channels give rise to competition for the same customers. Nonoverlapping service channels often mean that the other party has no service channel at all - it functions as a product provider and uses its associates' sales force(s) to reach its customers.

Alliance of independent partners. This alliance type is a special case of a cross-selling agreement where the alliance is tightened by cross-ownership and/or joint ownership in third parties. Cross-ownership means a minority stake of the other party's shares. If the ownership were one-sided, it would probably be a sign of asymmetry and one party's dominance of the alliance. An example of joint ownership is a mutual fund management company owned jointly by a bank, or banks, and an insurance company, or insurance companies. One could also think about cross-ownership/joint ownership without a cross-selling agreement, but such a model seldom occurs in practice. Also, this alliance category can, naturally, be divided into two subcategories depending on whether the parties' service channels are overlapping or not.

Control by ownership. A weakness in both the previous models is that it can be difficult to satisfy each alliance member with respect to the division of earnings and costs. This can be avoided by concentrating all the control in one of the alliance members. (This is called 'bancassurance' if a bank has taken control. The opposite model 'assurfinance' is not considered to be so effective. Van den Berghe and Verweire $^{22}$ claim that the only successful route in this respect is buying an existing bank instead of establishing one from scratch. Benoist ${ }^{23}$ comments on assurfinance in further detail.) There are two ways of implementing control by ownership: a bank can simply own (a control of) an insurance company or vice versa. In a more sophisticated ownership model, a holding company owns a number of banks and insurance companies. It is for this structure that we use the term 'financial conglomerate'. This is a result of a cross-segment consolidation. Recently, consolidation has also been happening across countries ('cross-geography consolidation').

An example of a financial conglomerate that offers its customers a large portfolio of financial services is Citigroup. ${ }^{24}$ Some firms, like ING, have chosen to specialize in just a few select services. ${ }^{25}$ Kist $^{26}$ points out that the premise for creating such conglomerates is to create value for all stakeholders, that is, shareholders, employees, and, most important, their clients. He also defines an integrated financial services company (IFS) as an organization that provides insurance, banking, and asset

\footnotetext{
${ }^{22}$ Van den Berghe and Verweire (2001).

${ }^{23}$ Benoist (2002).

${ }^{24}$ Carow (2001); Ryan (2001).

${ }^{25}$ Ryan (2001); Kist (2001).

${ }^{26}$ Kist (2001).
} 
management products to its customers through a variety of distribution channels. IFS can be understood as a well-integrated financial conglomerate. It has the unique ability to develop tailor-made banking, insurance, and asset management products for its customer base. ${ }^{27}$ Being a conglomerate increases the number of opportunities for diversification. For instance, it enables greater geographic diversification. The Nordic Swedbank, Nordea, and Sampo, for example, have successfully established themselves in the states around the Baltic Sea.

Only recent literature is available concerning alliance models and it is scarce. The division of the models mentioned by Van den Berghe and Verweire ${ }^{28}$ is otherwise similar to ours but they do not differentiate between overlapping and nonoverlapping service channels. The model classification by Benoist ${ }^{29}$ is somewhat different including, for example, franchise agreements and joint ventures that have not been used in the Nordic countries.

In Finland, there are examples of most of the aforementioned alliance categories: the Okobank group, Fennia Insurance group, and the Local Insurance group have a cross-selling agreement with overlapping service channels; Genworth Financial has a one-sided sales agreement with several financial institutions with no overlapping service channels; the nonlife insurer Pohjola, the life insurer Suomi, and 32 local savings banks have an alliance of independent partners with overlapping service channels and with joint ownership in a mutual fund management company and a retail bank; control by ownership has been adopted by banks like OP Group and Handelsbanken by establishing or acquiring a life insurance company, and by Tapiola Insurance group by establishing a bank; and finally, Sampo Group is an example of a financial conglomerate (see also Figure 1). Because there are so many models in real use in Finland, the problem of selecting the most attractive model is most relevant.

\section{Criteria for model comparison}

The alliance models described in the previous section shall be compared and eventually prioritized according to the following criteria. The decision maker here is the top management of a financial enterprise, which is considering various ways to create a financial alliance. Another possible and interesting point of view would be that of a supervisory authority, but we do not discuss it here.

The criteria are here understood as objectives that should be optimized. They are not necessarily quantitative. The criteria we suggest here are as follows:

1. maximize the efficiency of product development, especially the design of combination (hybrid) products,

2. implement the one-door-principle as effectively as possible,

3. compromise possibly conflicting earnings logics as well as possible,

\footnotetext{
${ }^{27}$ Ibid.

${ }^{28}$ Van den Berghe and Verweire (2001).

${ }^{29}$ Benoist (2002).
} 


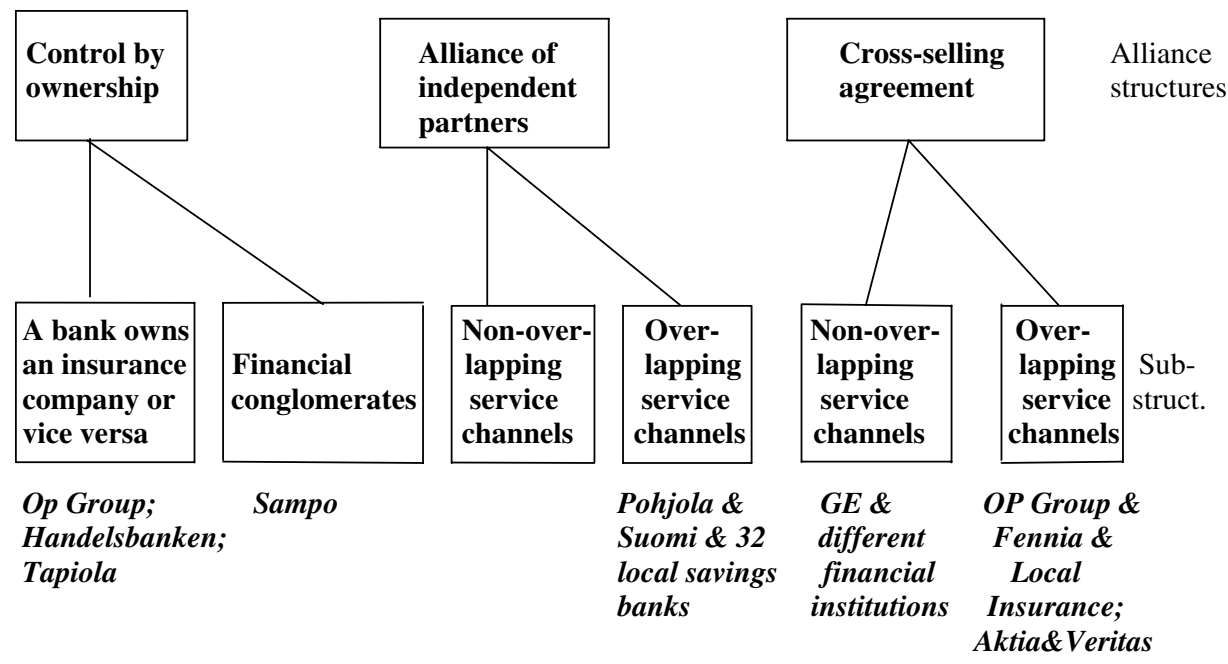

Figure 1. Examples of structure models adopted in Finland.

4. maximize the efficiency of customer relationship management,

5. optimize cost and revenue synergies,

6. minimize channel conflicts,

7. optimize required solvency capital,

8. maximize investor power,

9. maximize the efficiency of sales management.

Let us take a closer look at these criteria.

\section{Maximize the efficiency of product development}

Quality of product development is essential for any financial institution, and it is useful to be able to control it through cooperating partners. Combination products such as, for example, a loan and a loan protection insurance, or a mortgage loan connected to a mutual fund savings plan, are a way of packaging different offerings together and deepening customer relations. Van den Berghe and Verweire $^{30}$ give an interesting view of the future of integrated financial services. They point out that one does not need an integrated group of financial suppliers to offer integrated products. If distribution is able to offer client-oriented financial services from different financial services providers, they might evolve to become important players in the financial sector.

Decreasing active age groups and growing old age groups cause a serious financing problem for entire national economies. Nguyen ${ }^{31}$ examines the optimal pension model and its influence on individual saving behaviour, especially under the influence of an

\footnotetext{
${ }^{30}$ Van den Berghe and Verweire (2001).

${ }^{31}$ Nguyen (2003).
} 
ageing population. Demange and Laroque ${ }^{32}$ study the functioning of social security schemes under demographic shocks. On the micro-level, we shall probably witness the creation of more long-term savings products with tax incentives with which individuals can complement mandatory social security systems. This again calls for the successful combination of various financial products. Benoist ${ }^{33}$ points out that in the U.K. and Germany the creation of stakeholder pensions has increased the potential benefits of mergers and alliances between bankers and insurers. Ryan ${ }^{34}$ anticipates new markets for individual pension products and, more generally, products that provide financial security in old age.

\section{Implement the one-door-principle as effectively as possible}

One-door-principle means that a customer is offered as many bank and insurance products as possible at one place during one customer service event. The objective is full customer service at one stop and, thus, again packaging different products together and deepening customer relations. Benoist $\mathrm{t}^{35}$ concludes that this makes life easier for clients. Van den Berghe and Verweire ${ }^{36}$ discuss one-door-principle and conclude that it suits some customers, while others prefer shopping around themselves. Bank Marketing Internationa $\left.\right|^{37}$ claims that customers are not very interested in onestop shopping.

3. Compromise possibly conflicting earnings logics as well as possible

In an alliance, partners have to fit together their earnings logics. From one alliance member's point of view control over the other members obviously helps to optimize the result. An interesting study on the development of the earnings logics of members of a complex business network is given in Pelkonen and Dolakia. ${ }^{38}$

\section{Maximize the efficiency of customer relationship management}

Customer-orientation means, for example, selecting the customer's needs as a basis for business generation, and tailoring the service according to the business volume generated by the customer. The customer is given a responsible contact person, and uniform service through the organization is secured by sufficient internal training. Customer orientation must also show in provision structures: the customer does not nowadays accept being forgotten after the sales transaction, and provision structure must reward the salesperson for the long-term care of the customer. According to Ryan, ${ }^{39}$ most Americans maintain relationships with several different financial services providers but recent surveys show that over 50 per cent of consumers want to consolidate their financial relationships. The change in insurance customers' behaviour and expectations is discussed, for example, by the European Commission. ${ }^{40}$

\footnotetext{
${ }^{32}$ Demange and Laroque (2001).

${ }^{33}$ Benoist (2002).

34 Ryan (2001).

${ }^{35}$ Benoist (2002).

${ }^{36}$ Van den Berghe and Verweire (2001).

${ }^{37}$ Bank Marketing International (2004).

${ }^{38}$ Pelkonen and Dolakia (2003).

${ }^{39}$ Ryan (2001).

${ }^{40}$ European Commission (1996, p. 5).
} 
Financial institutions have parallel service channels such as physical branch networks, various agents, the internet, call centres, mobile devices, etc. The principle should be that the customer can choose the channel(s) he/she wants to use. Kist ${ }^{41}$ prioritizes an IFS (see previous section) because of its ability to have multiple distribution channels that have the means to approach customers in a variety of ways, that is, click, call, and face - as defined by Kist. Integrating various channels and inter-channel customer information transfer are challenges for a financial institution even without any alliance structure. More generally, customer relationship management (CRM) requires significant IT investments and continuous development. ${ }^{42}$

5. Optimize cost and revenue synergies

Scale benefits are obvious in the production of many financial products. They have traditionally been utilized by means of consolidation within the banking/insurance sectors. ${ }^{43}$ Cross-sector utilization evidently requires consolidation, too. According to Kist, ${ }^{44}$ some ways to gain maximum advantage with an IFS (see previous section) are to integrate risk management activities across the group, develop consistent financial reporting performance measures across all business types, and implement shared services for technology, accounting, and human resources. A great source of synergy is the ability to combine the previously separate asset management functions across the company into a single management structure.

Among other reasons, changing customer behaviour tends to make it necessary to reduce service channels, most of all branch networks. Eliminating overcapacity is, at least in principle, a more straightforward action when one member of the alliance has control over the others. On the other hand, integration creates overlapping functions that have to be streamlined. In the case of looser alliances, one-door-principle makes it possible to get rid of branch overload. For other cost and revenue synergies, see Kist. ${ }^{45}$ Diversification gains from combining banking and insurance are discussed by Estrella. $^{46}$

\section{Minimize channel conflicts}

A channel conflict can occur when the channels of alliance partners cross-sell each other's products to the same customers. Then the branch staff may think that the other party is stealing their provisions by cross-selling 'their' product to their customer. Sometimes an alliance member can fear that when they have cross-sold a customer their partner's product, the partner uses the acquired customer information when selling him/her another product competing with the original company's products. Minimizing channel conflicts is strategically important to the success of an alliance and it has to show in the cross-selling agreements. Channel conflict may also lead to fragmentation of the client base and/or ring-fencing of product offers (offers labelled

\footnotetext{
${ }^{41}$ Kist (2001).

${ }^{42}$ See also Kist (2001) for customer value management. A theoretical approach to CRM in insurance is given by Schäfer (2000).

${ }^{43}$ See, for example, Focarelli et al. (2002).

${ }^{44}$ Kist (2001).

45 Ibid.

${ }^{46}$ Estrella (2001). See also Vander Vennet (2002) and Casu and Girardone (2004).
} 
336

'bank' or 'insurance ${ }^{47}$ ). Channel conflict management, especially in financial distribution networks, is covered by Dolder et al. ${ }^{48}$

7. Optimize required solvency capital

The return on equity (ROE) is one of the most important performance measures in financial enterprises. Therefore, company management must carefully optimize the relation between working capital and balance sheet. In Finland, this ratio is on the average around 10 per cent, which means that the Finnish life insurance companies have the capital of two billion euros in addition to the technical reserves. (Schroder et $a l .{ }^{49}$ show that unit-linked insurance has improved profit margins compared with with-profits life insurance in France, Germany, the Netherlands, and Belgium. One important reason is lower working capital requirement. Trapp ${ }^{50}$ calls for new business models for weakly capitalized insurance companies.)

Traditionally, one important incentive for mergers and acquisitons is diversification of the business portfolio. In principle, a financial conglomerate has greater flexibility and greater opportunity for diversification than a simple combination. ${ }^{51}$ If there are several consolidated banks and insurance companies under the same control, it is crucial whether or not the different companies equalize or amplify each other's business cycles. In the latter case, a group may be forced to complement its solvency capital as the bottom of the cycle approaches. This has caused serious discussion of the justification of cross-sector consolidation in many parts of Europe. It seems from practical experience that the business cycles of traditional (with-profits) life insurance and retail banking correlate strongly, but nonlife/risk life insurance and retail banking are less correlated. ${ }^{52}$

Consolidated financial groups must have strong risk management capabilities. Information concerning risks can be used to determine the required levels of economic capital within each business unit and at the group level. ${ }^{53}$ Also, the successful leveraging of risk management professionals between the banking and insurance businesses can create much synergy. Furthermore, banks and insurance companies can provide each other a partial hedge of their natural asset liabilities mismatch positions.

8. Maximize investor power

If two companies are consolidated, the investor power is often more than doubled because certain fixed minority limits may be exceeded. For this reason, consolidated structures may be favoured because conflicting interests of independent partners might prevent them from utilizing this phenomenon in practice. Besides direct share ownership, discretionary asset management and mutual fund management mandates give investor power. Theoretical implications of increasing investor power are studied by Ryan and Schneider. ${ }^{54}$

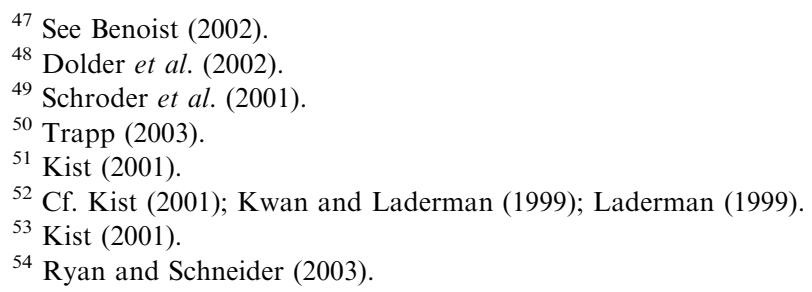




\section{Maximize the efficiency of sales management}

Centralized sales management obviously requires centralized organizational structure, that is, consolidation. One might presume that this is a benefit compared to the decentralized management of looser alliances. However, some partners with a plain cross-selling agreement claim that they have succeeded in creating a very effective 'cross-selling culture'. This possibility is supported by Van den Berghe and Verweire. ${ }^{55}$ Kumar $^{56}$ covers sales organization issues in a financial alliance.

In order to evaluate the attractiveness of the various alliance structures presented in the previous section in the light of the above nine criteria, we wish to point out the following:

- Although the literature seems to favour financial conglomerates, it is by no means granted that they are optimal in all circumstances.

- Even if control by ownership were preferred, it may be found to be difficult or impossible to implement. That is the case, for example, for many local banks and mutual insurance companies.

- It is certainly more attractive to control than to be controlled. In the case of the financial conglomeration, the solution for the owners of a company to be acquired could be accepting shares of the acquiring company as the purchase price.

\section{Expert interviews}

We have interviewed the experts listed in the Acknowledgements section and asked their opinions on the alliance structure models and the criteria explained in the previous two sections.

One of the major benefits of tighter alliance models is that, for example, 'control by ownership' prevents or at least strongly restricts channel conflicts. Some experts pointed out, however, that well-written sales agreements minimize, if not totally prevent, channel conflicts. Furthermore, protecting customer relations and fundamental business lines was considered more important than immediate returns.

It was generally acknowledged that the six models presented succeed in separating various real-life alliances quite well, at least in the Finnish market. In fact, as recently as November 2003 there would have been Finnish examples in every category.

Several experts paid attention to the top management point of view in the MCDM problem. Some of them asked whether it is somehow different from the shareholder's perspective. If the top management incentives are appropriate and good corporate governance is also otherwise followed, there is hardly any significant difference. The situation may change if a shareholder has important holdings in several financial enterprises.

\footnotetext{
55 Van den Berghe and Verweire (2001).

${ }^{56}$ Kumar (2001).
} 
One expert remarked that the second criterion could be stated in a more general way, for example 'create as effective sales channels as possible'. However, the author has noticed, while planning several financial alliances in recent years, that the onedoor-principle has always been among the objectives. The suggested generalization is actually a part of the ninth criterion.

An expert suggested a more descriptive name for the third criterion: 'ensure as fair division of earnings and costs as possible'. The fourth criterion could, according to an expert, be defined as 'enable effective cross-selling'.

As already pointed out in the previous section, channel conflicts should be understood so widely that they include conflicts between product companies. An expert suggested, with good reason, that the sixth criterion should be called 'minimize interest conflicts between service channels and between product companies'. Channel conflicts may occur also in financial conglomerates. For example, savings insurance and deposits compete for the same customers. This problem can be solved by good steering systems. For instance, salespersons should get sufficient reward for selling other business units' products and creating successful contacts between their customers and other business units. Thus, they become 'group salespersons'.

The seventh criterion actually includes a whole MCDM problem, the most important objective of which could be 'maximize ROI'. Here the time horizon is crucial. If solvency requirements for certain business lines are relatively lower than for other lines, there is a possibility for arbitrage.

The eighth criterion was given minimal weight by some experts, while others remarked that even if institutional investors in Finland do not so often participate in board work, they use their power in annual shareholders' meetings. It is also becoming more common that they participate in board and compensation committee work. Finnish life insurance companies have, at least so far, been more active investors than, for example, fund management companies.

One of the experts suggested an additional tenth criterion: 'Optimize the stable competitive position'. Because many criteria already represent various aspects of this criterion, we decided not to add it. Another suggestion for a new criterion was to 'minimize the (negative) effects of the changes in operational environment'. We did not accept this criterion for our list either, because it is not very concrete and, again, existing criteria cover several aspects of it.

One expert pointed out that now that we had, in a sense, nine objective functions, we should keep in mind the restrictions, that is, licence regulations and minimum solvency requirements.

The criteria are, obviously, partially over-lapping, but no criterion covers another criterion in full. Therefore, there is no need to 'merge' criteria. Inserting new criteria did not seem useful either. Financial conglomerates may suffer from intrigues and suboptimization, but these phenomena can be done away with by a competent management. One of the experts remarked that in other alliance models than 'control by ownership' much better sales results can be achieved if there are other partners' sales experts in the top management of each company. Finally, people - and not only the model - are decisive. 
Table 1 Relationship between models and criteria

\begin{tabular}{llllllllll}
\hline Criterion & 1 & 2 & 3 & 4 & 5 & 6 & 7 & 8 & 9 \\
\hline Model & 2 & 2 & 2 & 2 & 3 & 2 & 3 & 2 & 2 \\
CBO1 & 2 & 2 & 2 & 2 & 3 & 2 & 3 & 2 & 2 \\
FC & 2 & 2 & 3 & 2 & 2 & 1 & 1 & 1 & 2 \\
AIP1 & 2 & 2 & 3 & 2 & 2 & 3 & 1 & 1 & 2 \\
AIP2 & 2 & 2 & 3 & 2 & 2 & 1 & 1 & 1 & 2 \\
CSA1 & 2 & 2 & 3 & 2 & 2 & 3 & 1 & 1 & 2 \\
CSA2 & 12 & 12 & 16 & 12 & 14 & 12 & 10 & 8 & 12 \\
$\sum$ & & & & & & & & & \\
\hline
\end{tabular}

Keeney and Raiffa ${ }^{57}$ present the following desirable properties for a set of criteria:

- complete, it covers all the important aspects of the problem;

- operational, it can be meaningfully used in the analysis;

- decomposable, all the aspects of the evaluation process can be simplified by breaking it down into parts;

- nonredundant, the double counting of impacts can be avoided; and

- minimal, the problem dimension is kept as small as possible.

According to the interviews, our set of nine criteria satisfies these conditions at an acceptable level.

In view of the expert interviews, the mutual importance of the criteria can be evaluated in the following way: let us abbreviate the alliance models that appear in Figure 1 by CBO1, FC, AIP1, AIP2, CSA1, and CSA2, in the same order. Let us consider a matrix $X=\left(x_{i j}\right)$, which relates the models and the criteria and whose elements are defined as follows:

$$
x_{i j}= \begin{cases}1 & \text { if the criterion } j \text { is not important in the model } i \\ 2 & \text { if the criterion } j \text { is rather important in the model } i \\ 3 & \text { if the criterion } j \text { is very important in the model } i\end{cases}
$$

The matrix $X$ can be derived from the interviews (Table 1).

For both control by ownership models $\mathrm{CBO} 1$ and FC, the criteria 5 (synergies) and 7 (solvency capital) are the most important. For both models with no overlapping service channels AIP1 and CSA1, criterion 3 (earnings logics) is the most important, and for both models with overlapping service channels AIP2 and CSA2, the criteria 3 and 6 (channel conflicts) are the most important. The last row of Table 1 shows the overall importance of each criterion as the sum of the corresponding column elements.

\footnotetext{
${ }^{57}$ Keeney and Raiffa (1976, pp. 50-53).
} 


\section{Conclusion}

We have structured the ill-defined problem of finding the most preferred financial alliance structure as a multi-criteria decision-making problem. The problem is how to rank the alliance models presented in the third section according to the criteria presented in the fourth section considering that the criteria are difficult to quantify and measure in a harmonious way. The problem has been defined together with the experts, and the choice of the criteria is based on their views.

The problem can be solved tentatively as follows: when we consider the last row of Table 1, we find out that the overall importance of criteria 3 (earnings logics), 5 (synergies), and 6 (channel conflicts) is the greatest. (Criterion 6 is chosen from those that received the same score of 12 because it is the only one that received a score of 3 indicating great importance.) Earnings logics are fitted together and channel conflicts settled most effectively in the models CBO1 and FC because there is a unique company highest in the ownership hierarchy, which makes the ultimate decisions. Synergies are commonly believed to be best achieved in the same models because the necessary rational business decisions are made especially efficiently by the single leader company. Because the control by ownership models $\mathrm{CBO} 1$ and $\mathrm{FC}$ are the best models to satisfy the most important criteria, we conclude that they are the most attractive alliance models from the executive management point of view.

The reader may want to use this problem or perhaps modify it and then use it in his/ her decision-making. We are going to solve the problem with some more sophisticated algorithm that enables us to differentiate between all the models. We shall report the results at a later date.

\section{Acknowledgements}

I thank Professor Pekka Korhonen from the Helsinki School of Economics for his valuable advice and encouragement during the processing of this paper. I also thank the following interviewed experts for kindly commenting on the models and criteria presented above.

Mikael Ingberg, Managing Director, Aktia Savings Bank

J.-P. Halmeenmäki, Managing Director, Tapiola Life Insurance

Seppo Ilvessalo, Director, Suomi Life Insurance

Harri Kainulainen, Managing Director, Local Insurance Group

Hannu Linnoinen, Deputy Managing Dir., Pohjola Insurance Group

Petri Niemisvirta, Managing Director, Sampo Life Insurance

Matti Ruohonen, Managing Director, Veritas Life Insurance

Pauli Sarelius, Deputy Managing Dir., Okobank Life Insurance

Timo Tuomenpuro, Chief Strategist, Pohjola Insurance Group

Markku Vesterinen, Deputy Managing Dir., Suomi Life Insurance

\section{References}

Bank Marketing International (2004) Mega-mergers: The customer suffers (February), p. 9.

Benoist, G. (2002) 'Bancassurance: The new challenges', The Geneva Papers on Risk and Insurance 27(3): 295-303. 
Bittermann, L. and Lutz, A. (2003) 'Parallelen im Risikomanagement von Banken und Versicherungen', Versicherungswirtschaft 6: 391-393.

Boyd, J.H. and Graham, S.L. (1988) 'The profitability and risk effects of allowing bank holding companies to merge with other financial firms: A simulation study', Federal Reserve Bank of Minneapolis Quarterly Review 12: 3-20.

Boyd, J.H., Graham, S.L. and Hewitt, R.S. (1993) 'Bank holding company mergers with non-bank financial firms: Effects on the risk of failure', Journal of Banking and Finance 17: 43-63.

Carow, K.A. (2001) 'Citycorp-Traveler group merger: Challenging barriers between banking and insurance', Journal of Banking and Finance 25: 1553-1571.

Casu, B. and Girardone, C. (2004) 'Financial conglomeration: Efficiency, productivity and strategic drive', Applied Financial Economics 14: 687-696.

Cybo-Ottone, A. and Murgia, M. (2000) 'Mergers and shareholder wealth in European banking', Journal of Banking and Finance 24: 831-859.

Demange, G. and Laroque, G. (2001) 'Social security with heterogeneous populations subject to demographic shocks', The Geneva Papers on Risk and Insurance Theory 26: 5-24.

Dolder, C., Hobbs, M., McDonald, M. and Wilson, H. (2002) Optimising multi-channel performance, A joint IBM/Cranfield University School of Management white paper.

Estrella, A. (2001) 'Mixing and matching: Prospective financial sector mergers and market valuation', Journal of Banking and Finance 25: 2367-2392.

European Commission (1996) Economic aspects of insurance distribution.

Focarelli, D., Panetta, F. and Salleo, C. (2002) 'Why do banks merge', Journal of Money, Credit, and Banking 34: 1047-1066.

Focarelli, D. and Pozzolo, A.F. (2001) 'The patterns of cross-border bank mergers and shareholdings in OECD countries', Journal of Banking and Finance 25: 2305-2337.

Generale, A. and Gobbi, G. (1999) 'Corporate governance and bank profitability: Empirical evidence from the Italian experience, The monetary and regulatory implications of changes in the banking industry', BIS Conference Papers 7: 34-54.

Keeney, R.L. and Raiffa, H. (1976) Decisions with Multiple Objectives, Preferences, and Value Tradeoffs, Cambridge: Cambridge University Press.

Kist, E. (2001) 'Integrated financial services - A framework for success: Synergies in insurance, banking, and asset management', The Geneva Papers on Risk and Insurance 26: 311-322.

Kumar, M. (2001) Marketing and Distribution Channels in Bancassurance, CEO summit of banks and insurance companies of Asia Pacific countries, October 2001, Singapore.

Kwan, S.H. and Laderman, E.S. (1999) 'On the portfolio effects of financial convergence - A review of the literature', Federal Reserve Bank of San Francisco Economic Review 2: 18-31.

Laderman, E.S. (1999) The potential diversification and failure reduction benefits of bank expansion into nonbanking activities, working paper, Federal Reserve Bank of San Francisco.

Lown, C.S., Osler, C.L., Strahan, P.E. and Sufi, S. (2000) The Changing Landscape of the Financial Services Industry: What Lies Ahead?, Federal Reserve Bank of New York, Conference on Specialization, Diversification and the Structure of the Financial System: The Impact of Technological Change and Regulatory Reform.

Manghetti, G. (2002) 'Multinational insurance groups: The main problems for supervisors', The Geneva Papers on Risk and Insurance 27: 310-319.

Nguyen, T. (2003) 'Der Einfluss einer alternden Bevölkerung auf die Rentenversicherung bei unsicher Lebenserwartung', Zeitschrift fur die gesamte Versicherungswissenschaft 1: 129-159.

OECD (1998) 'Competition issues arising in the insurance and financial services industries', $O E C D$ Background Note, DAFFE/CLP 98.

Pelkonen, T. and Dolakia, N. (2003) 'Understanding emergent M-commerce services by using business network analysis: The case of Finland', in N. Shi (ed) Wireless Communications and Mobile Commerce, Chicago, IL: Independent Publishers Group, pp. 105-131.

Ryan, A. (2001) 'Financial regulation and the convergence scenario', The Geneva Papers on Risk and Insurance 26: 44-53.

Ryan, L. and Schneider, M. (2003) 'Institutional investor power and heterogeneity - Implications for agency and stakeholder theories', Business \& Society 42: 398-429. 
342

Schroder, Salomon Smith and Barney (2001) European Life Insurance, An examination of profitability.

von Schäfer, H. (2000) 'Kundenbindung in der Versicherungswirtschaft - neo-institutionenökonomische Analyse und Marketingpolitische Ansatzpunkte', Zeitschrift fur die gesamte Versicherungswissenschaft 1: 89-120.

SIGMA (2003) 'Fondsgebundene Lebensversicherungen in Westeuropa: Erholung in Sicht?' Schweizerische Ruckversicherungs-Gesellschaft, Economic Research and Consulting, Ausgabe 3: 1-44.

Trapp, J. (2003) 'Die risikoorientierte Veränderung strategischer Geschäftsmodelle', Versicherungswirtschaft 19: 1484-1488.

Van den Berghe, L. and Verweire, K. (2001) 'Convergence in the financial services industry', The Geneva Papers on Risk and Insurance 26: 173-183.

Vander Vennet, R. (2002) 'Cost and profit efficiency of financial conglomerates and universal banks in Europe', Journal of Money, Credit, and Banking 34: 254-282.

Verweire, K. (1999) Performance consequences of financial conglomerates with an empirical analysis in Belgium and the Netherlands, Doctoral thesis, Thesis Publishers Amsterdam, Amsterdam.

\section{About the Author}

Raimo Voutilainen has held expert and executive positions in the insurance sector since 1980, especially in bancassurance environment. He is now finishing his Ph.D. studies in Helsinki School of Economics. The subject of his thesis is Alliances between banks and insurance companies. 